\title{
Using Additives for the Production of Castings from the Gray Cast Iron
}

\author{
Martina Hrubovčáková, Iveta Vasková, Martin Conev \\ Technical University of Kosice, Faculty of Materials, Metallurgy and Recycling, Institute of Metallurgy, Letná 9, 04200 \\ Košice, Slovakia. Contact: martina.hrubovcakova@tuke.sk.
}

The Cold-Box Amine method was developed in 1965 by Ashland. For more than 35 years, this method has been applied worldwide and has become the most important method of cold curing. The veining is characteristic defect of cast iron alloys, which accompanies the use of Cold Box-amine cores, the solution to this defect is the content of this paper. There are many factors that affect the surface of the casting and thus the formation of veining. In recent years, products have appeared on the market - additives to prevent veining. Castings using these products should have a smooth surface, no protrusions and other foundry defects. These products have their irreplaceable place on the foundry market, as it is often necessary to eliminate the castings that cannot be cleaned and therefore the veining cannot be removed on these castings. They are predominantly castings for the automotive industry, castings for the railway industry and, in the case of low-quality casting in these sectors, we can talk about gambling with human life. Therefore, it is necessary to pay attention to the occurrence of leaks on castings and to eliminate them with the use of the above-mentioned additives, but we must not forget about many other factors that support the creation of this foundry defect. The paper is devoted to the factors influencing the casting surface and, last but not least, to the used additives in foundries.

Keywords: veining, cold box, additives, grey cast iron

\section{Introduction}

The quality of castings produced is a decisive factor in their further use. In the foundry industry, it is very difficult, or even impossible, to produce castings without foundry defects. That is why we need to study these mistakes and the possibilities to remove them. One of the common foundry error on the rounded parts of castings is veining, that occurs either individually or in combination with other mistakes, most commonly with burn-on. Veining is characterized as veined or ribbed network cutouts on the casting surface. Primarily they arise as a result of the thermal expansion of the sand. The most commonly used sand is quartz, but it undergoes transformation changes, and as a result of these changes, stresses occur in the subsurface parts of the mold, causing rupture in the core where liquid metal can penetrate. Therefore, it is necessary to pay attention to the sand used. As mentioned, one of the causes of veining is the non-linear thermal expansion of the silica sand, so it is necessary to consider the modifications, replacing this quartz sand with others, with a linear thermal expansion. [1,2]

Another important factor is a used type of binder and its amount. Both binder components form a core molding mixture which is cured with a gaseous amine catalyst.

Another, now widely used method is the use of additives, i.e., auxiliaries, which are added to the core mixture in order to mitigate the resulting tension due to transformation of quartz sand. Additives reduce the temperature at which $\mathrm{SiO}_{2}$ begins to soften and form a melt on the grain surface, they increase reactivity and reduce the transition temperature to tridimite and cristobalite. These transitions support the increase in the volume of subsurface sand tension and reduce the tension to form the veining on the surface of the core or mold. The available literature discloses how these ingredients act in the mixture, it is clear that the manufacturers of these additives do not put in the technical data sheets of which these additives are manufactured, which component acts on the core mixture and how this material is used for casting. If we want to understand the behavior of these ingredients in the mixture, use them correctly and ensure their safe use throughout the casting cycle, attention should be paid to their analysis, which is the content of the experimental part of the work. [2,3]

In the literature, there are answers to questions about statements where they are found, how they affect the quality of castings, that they can be eliminated by change of sand, binder or adding additives, but as the other chapters of this work have shown, the number of influencing factors on the occurrence of veining is much bigger.

The essence of this work is the study of the foundry error called the veining on the castings. It should be stated that we have to look at complex views from multiple angles in connection with veining. This means that we must always take in consideration multiple factors at the same time. Otherwise, it may happen that the veining from the casting surface can be removed, but other errors may occur, such as burn-on, bumps or sand inclusion. $[4,5,6]$

The veining is formed primarily due to the tension created by the non-linear thermal expansion of the silica sand. It is an indisputable fact, however, which does not prevent the use quartz in foundries, especially because of its availability and economic efficiency. Therefore, it has been necessary to find other ways to remove the defect on the surface of castings, which are commonly used for the automotive industry or rail transport, where we speak in the case of the use of a poor casting about the risks of human life. [7]

\section{Experimental work}

Currently, there are a number of additives to improve the surface of the casting and significantly affect the quality of castings. Usually there are describe properties of 
the additives, but their chemical or mineralogical remains unclear. Therefore, if we want to evaluate their impact, these parameters must be known in order to achieve their effective use. From the point of view of veining elimination, use of additives is one of the easiest and most powerful methods, and therefore their analysis is very important. As the basic parameters are often not listed in the technical data sheets of the suppliers of these additives, several analyzes have been carried out to define the additives used in the foundries, namely the Antifin and Veinseal additives, which have been proven in the practical conditions. $[8,9,10]$
Based on the experience gained and the knowledge about the additives, there was an effort to prepare new types of additives which would achieve better results compared to those commercially used. The individual components of designed additives are labeled as:

A- carbon-based reducing agent

$\mathrm{B}$ - insoluble polysaccharide

C- iron oxides $\left(\mathrm{C} 1-\mathrm{Fe}_{2} \mathrm{O}_{3}, \mathrm{C} 2-\mathrm{Fe}_{3} \mathrm{O}_{4}\right)$

Tab. 1 presents the chemical composition of the prepared additives. The basis of the core mixture was $\mathrm{T}+\mathrm{T}$ silica sand, supplemented with components A, B or C, or their combinations.

Tab. 1 Chemical composition of prepared additives (in Weight \%)

\begin{tabular}{|c|c|c|c|c|c|c|c|c|c|c|c|c|c|c|c|}
\hline 导 & ర్ల & $\overbrace{\substack{\infty \\
\sum}}$ & 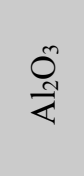 & 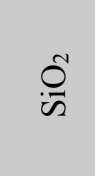 & $\overbrace{0}^{n}$ & $\begin{array}{l}0 \\
\mathbb{N}\end{array}$ & $\stackrel{O}{\Xi}$ & $\begin{array}{l}0 \\
0 \\
I\end{array}$ & 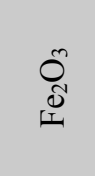 & $\begin{array}{l}0_{\infty}^{+} \\
\mathbb{0}\end{array}$ & $\stackrel{\circ}{\ominus}$ & 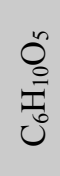 & $\frac{\tilde{E}}{\tilde{\Xi}}$ & 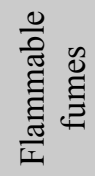 & $\circlearrowright$ \\
\hline $1: A+B$ & 1.82 & 6.65 & 2.3 & 56.92 & & & & & 6.68 & & & 30 & 12.9 & 1.34 & 85.32 \\
\hline 2: $\mathrm{C} 2+\mathrm{B}$ & 0.16 & 0.24 & 0.43 & 2.67 & 0.34 & 0.12 & & & & 67.16 & 0.15 & 30 & & & \\
\hline 3: C2 & 0.23 & 0.35 & 0.62 & 3.82 & 0.49 & 0.18 & & & & 95.96 & 0.22 & 0 & & & \\
\hline 4: $\mathrm{C} 1+\mathrm{B}$ & 0.84 & 0.36 & 2.65 & 7.12 & 0.39 & 0.16 & 0.030 & & 60.59 & & 0.077 & 30 & & & \\
\hline 5: C1 & 1.21 & 0.52 & 3.78 & 10.17 & 0.56 & 0.23 & 0.04 & & 86.56 & & 0.11 & 0 & & & \\
\hline
\end{tabular}

Prior to testing these new additives in practical conditions, tests of the prepared core mixtures were performed to determine the $\mathrm{R}$ coefficient of these mixtures Fig. 1. Coefficient $\mathrm{R}$ can be considered to be the rate of stress on the casting and thus the rate of formation of veining on the casting surface. In theory, the ratio of bending strength and tensile strength (1) is stated as one of the criteria for the evaluation of the core mixture.

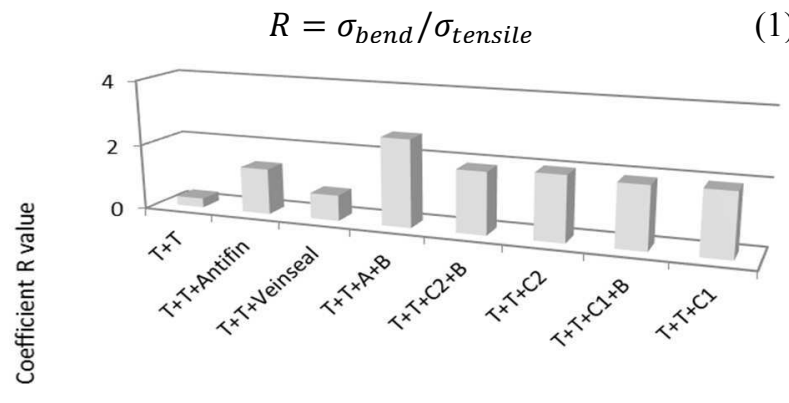

Core mixture composition

Fig.1 The coefficient $R$ for mixtures with new additives compared to conventional production

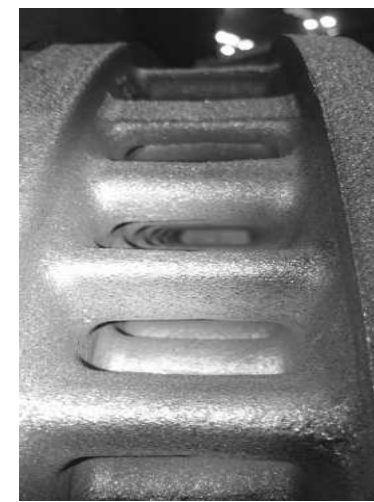

a) $\mathrm{A}+\mathrm{B}$

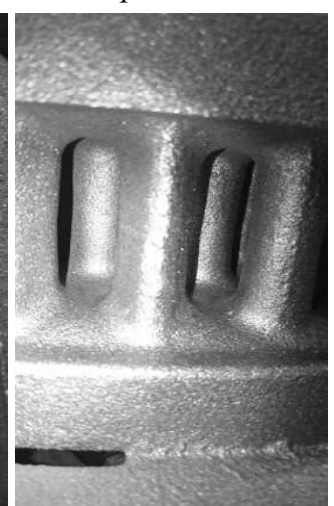

b) $\mathrm{C} 2+\mathrm{B}$

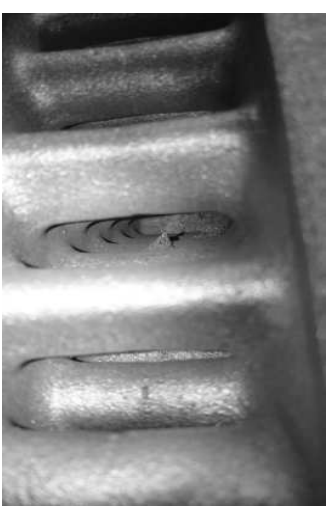

c) $\mathrm{C} 2$

After the coefficient $\mathrm{R}$ for new prepared core mixtures has been obtained, and given their chemical composition, which satisfies the conditions of the foundry, core mixtures with these additives were tested in the production. The results of these experiments are shown in Fig. 2 and Fig. 3.

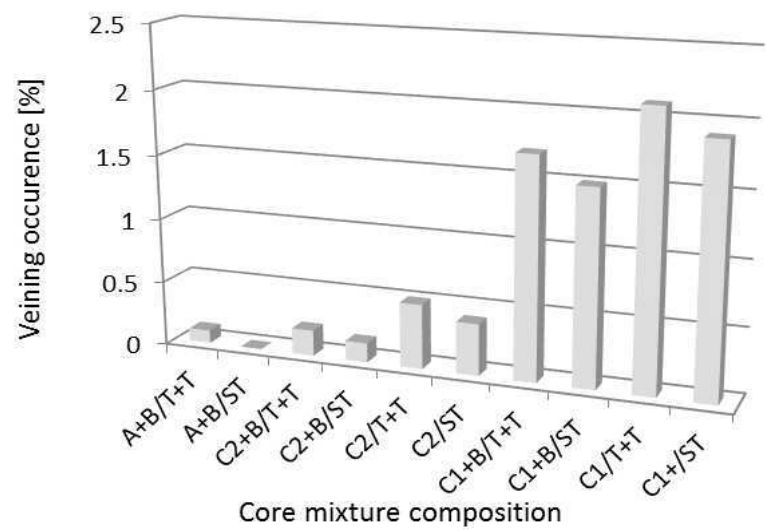

Fig. 2 Occurrence of veining on castings from the core mixture using new additives

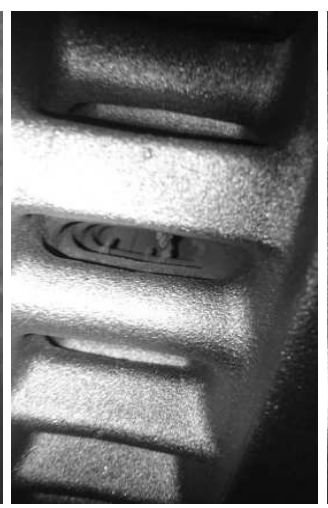

d) $\mathrm{C} 1+\mathrm{B}$

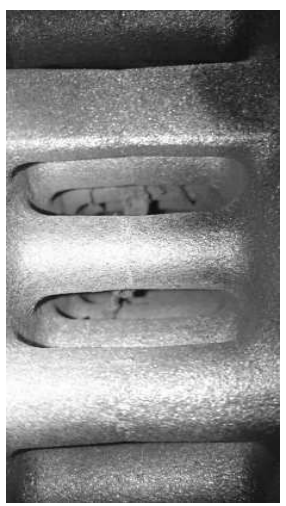

e) $\mathrm{C} 1$

Fig. 3 Castings made from $C B$-A cores using new additives 
After evaluating the surface of all castings produced using the new additives, we recommend using additive 1 , which contains components $\mathrm{A}+\mathrm{B}$, namely a carbonbased reducing agent and an insoluble polysaccharide. It is also possible to use additive 2, which main component are iron oxides $\mathrm{Fe}_{3} \mathrm{O}_{4}$, since they are able to create an endothermic reaction in the casting process (2), which significantly affects the casting surface.

$$
\mathrm{Fe}_{3} \mathrm{O}_{4}+\mathrm{mCO} \rightarrow 3 \mathrm{FeO}+\mathrm{CO}_{2}+(\mathrm{m}-1) \mathrm{CO}, \Delta \mathrm{H}_{298}^{\circ}=26,669 \mathrm{~kJ}
$$

The analysis of the new additive with a working title Surwaybest, which achieved the best laboratory and pracital results, is shown in Fig. 4 to Fig. 7.

As demonstrated by the phase composition analysis of the Surwaybest additive, the additive is composed of iron oxides - magnetit, which ensures the cooling effect of the additive by means of an endothermic reaction and also the formation of $\mathrm{FeO}$, which together with $\mathrm{SiO}_{2}$ ensures the formation of a phayalitic envelope on the sand grains, thus eliminating the subsurface tension in the core or mould. The Surwaybest further comprises an insoluble polysaccharide which warms upon casting of the mold / core to form a space for the expansion of the silica sand and additionally contains a larger amount of carbon than the commercial additives used so far. This results due to the heat of the molten metal to dehydrogenation and at the same time to softening and filling of the inter- space and coating of the individual grains (according to so-called coating theory). Fig. 8 shows a comparison of the phase composition of the additives used (antifine - red, Veinseal - blue) and the new additive Surwaybest (black). It is clear that Surwaybest is in the middle among the used additives, but with a larger amount of carbon, which will ensure

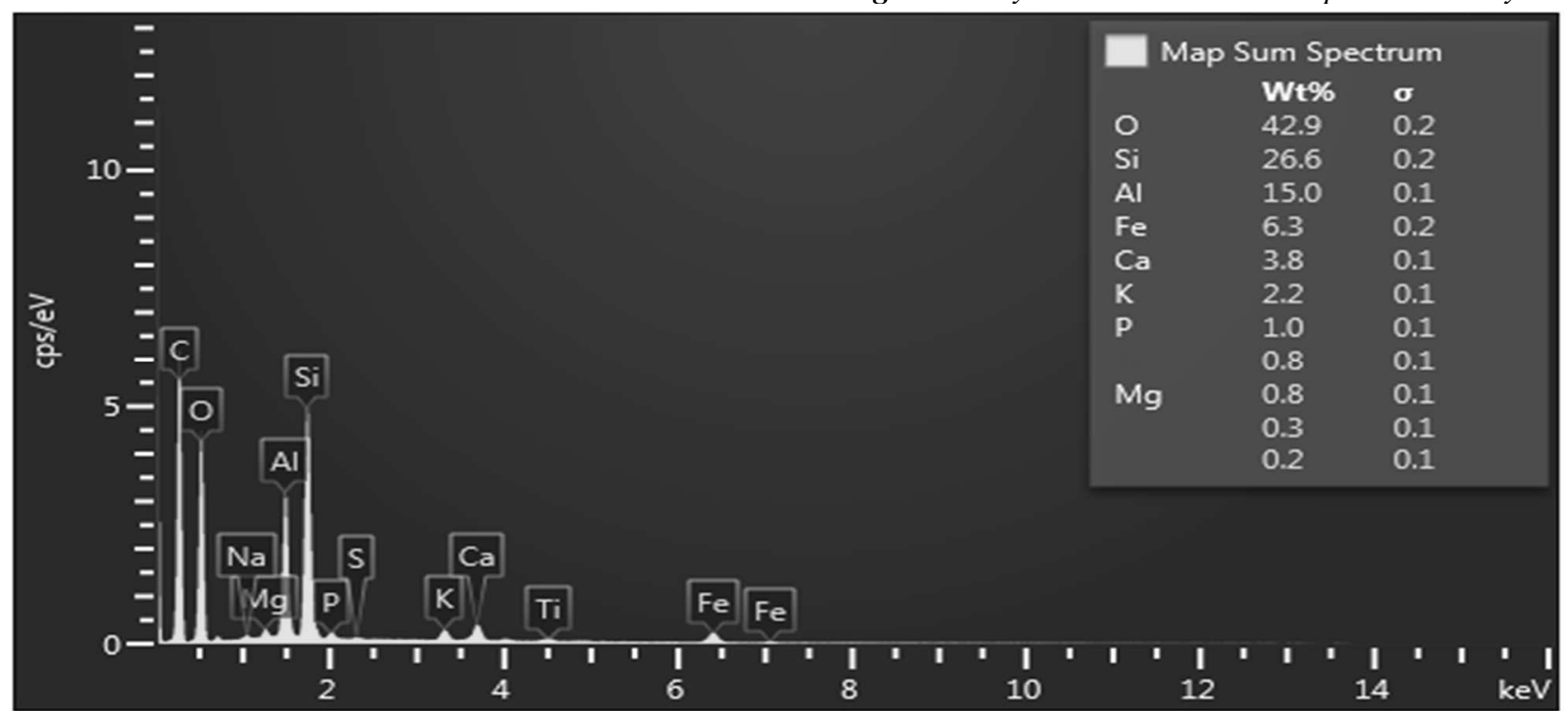

Fig. 5 Surwaybest additive Surface EDX analysis
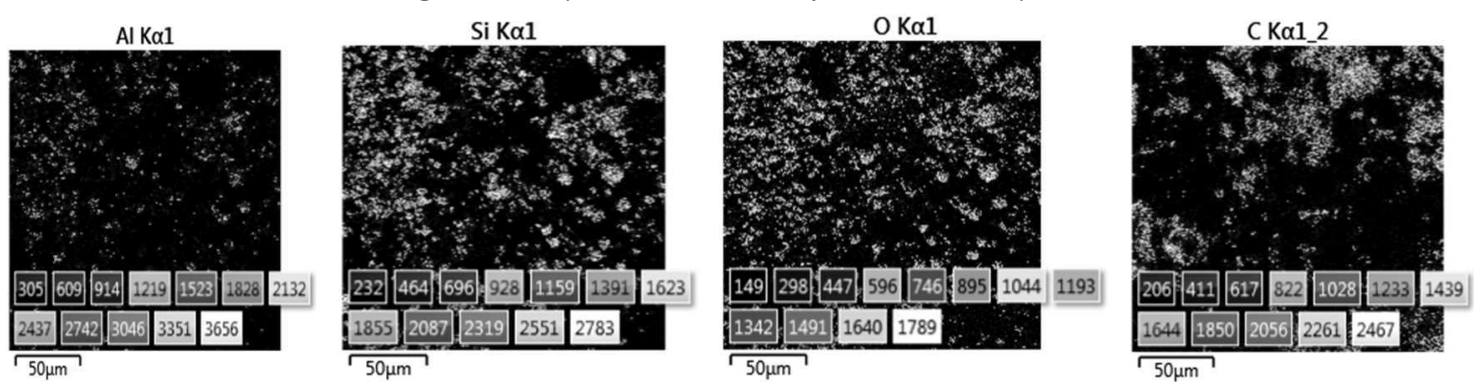

Fig. 6 Representation of individual elements in the Surwaybest additive obtained by surface EDX analysis the smooth surface of castings. The above mentioned additive was also used in the production of other castings and the results were always satisfactory. The surface of the castings was smooth, without veining and other foundry defects.

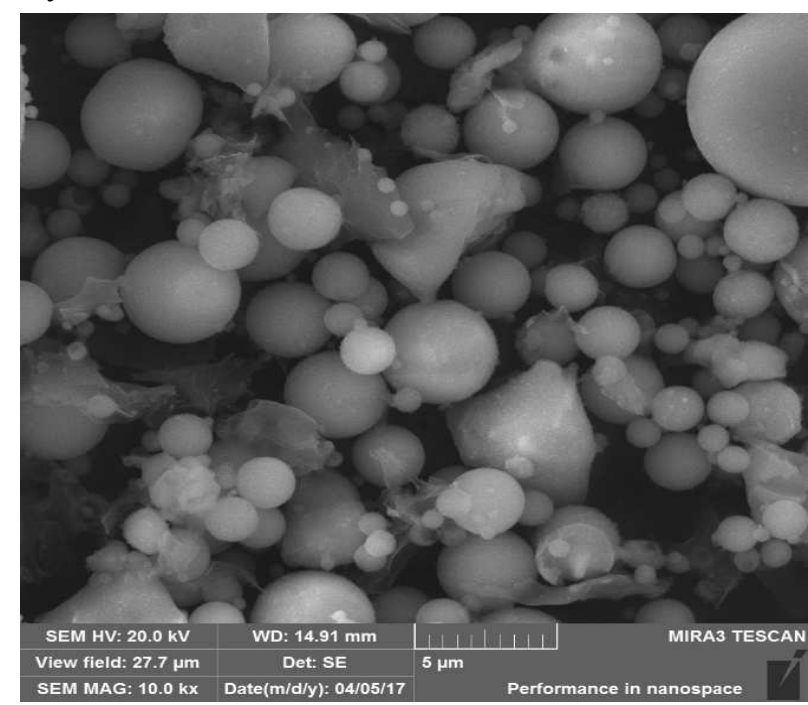

Fig. 4 Surwaybest additive Microscopic EDX Analysis 


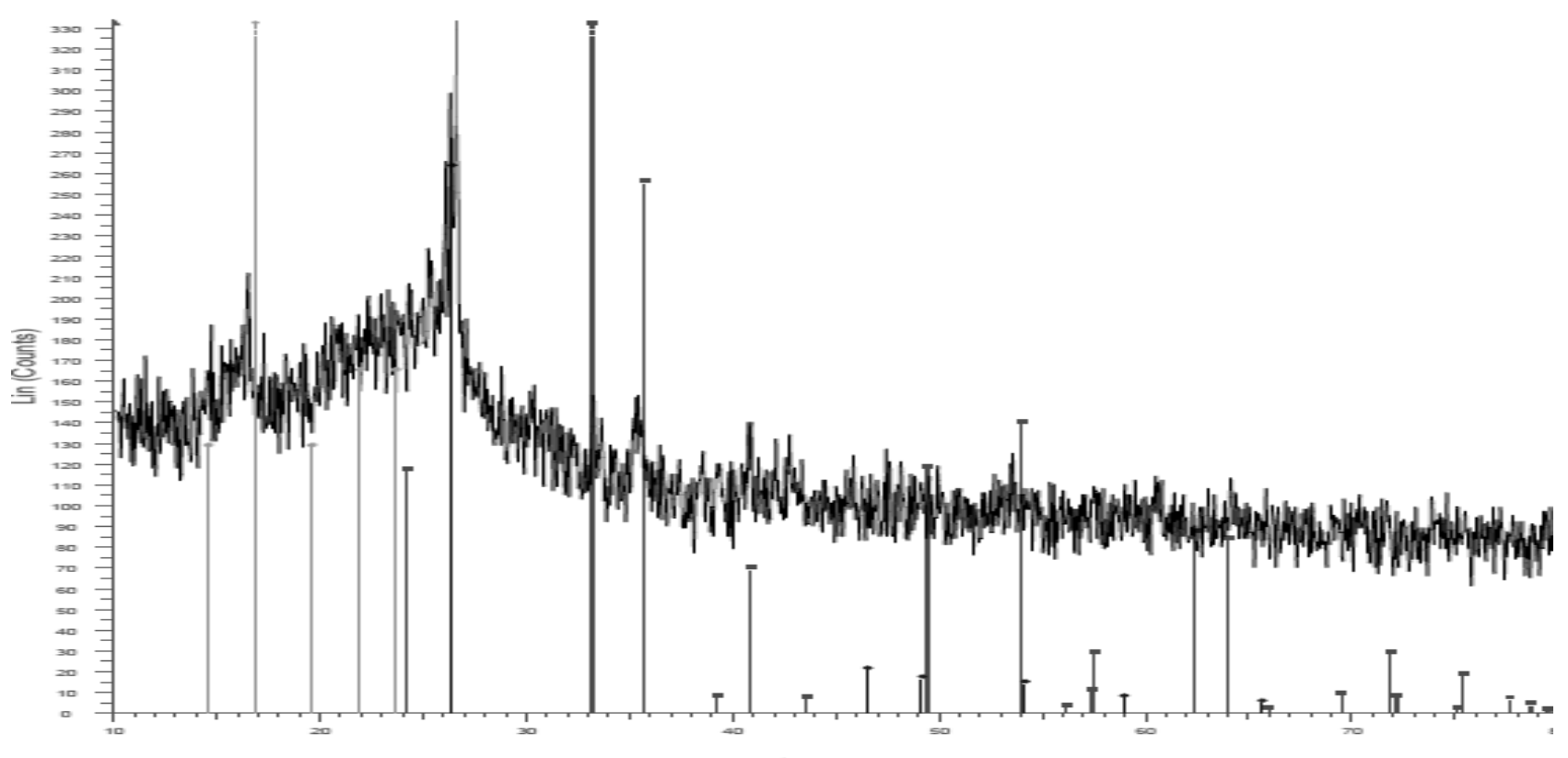

\section{2-Theta - Scale}

团A - File: AA.raw - Type: 2 Th/Th locked - Start: $10.000^{\circ}$ - End: $80.000^{\circ}$ - Step: 0.050 - Step time: 5.5 - Temp: $25^{\circ}$ (Room) - Time Started: 12 s - 2-Theta: 10.00 Operations: Import

D01-076-8393 (") - Hematte, syn - Fe203 - Y: $108.38 \%$ - d x by: 1. - WL: 1.5408 - Rhombo.H.axes - a 5.03513 - b 5.03513 - c 13.75800 - alpha 90.000 - beta 90.0

D1-075-0444 (I) - Carbon - C - Y: $78.87 \%$ - d x by: 1. - WL: 1.5406 - Rhombo.H.axes - a 2.29600 - b 2.29600 - c 10.15400 - alpha 90.000 - beta 90.000 - gamma 1 $000-055-1801$ (Q) - Starch (maize) - (C8H1005)n - Y: $100.18 \%$ - d x by: 1. - WL: 1.5408 -

Fig. 7 Phase composition of the designed Surwaybest additive

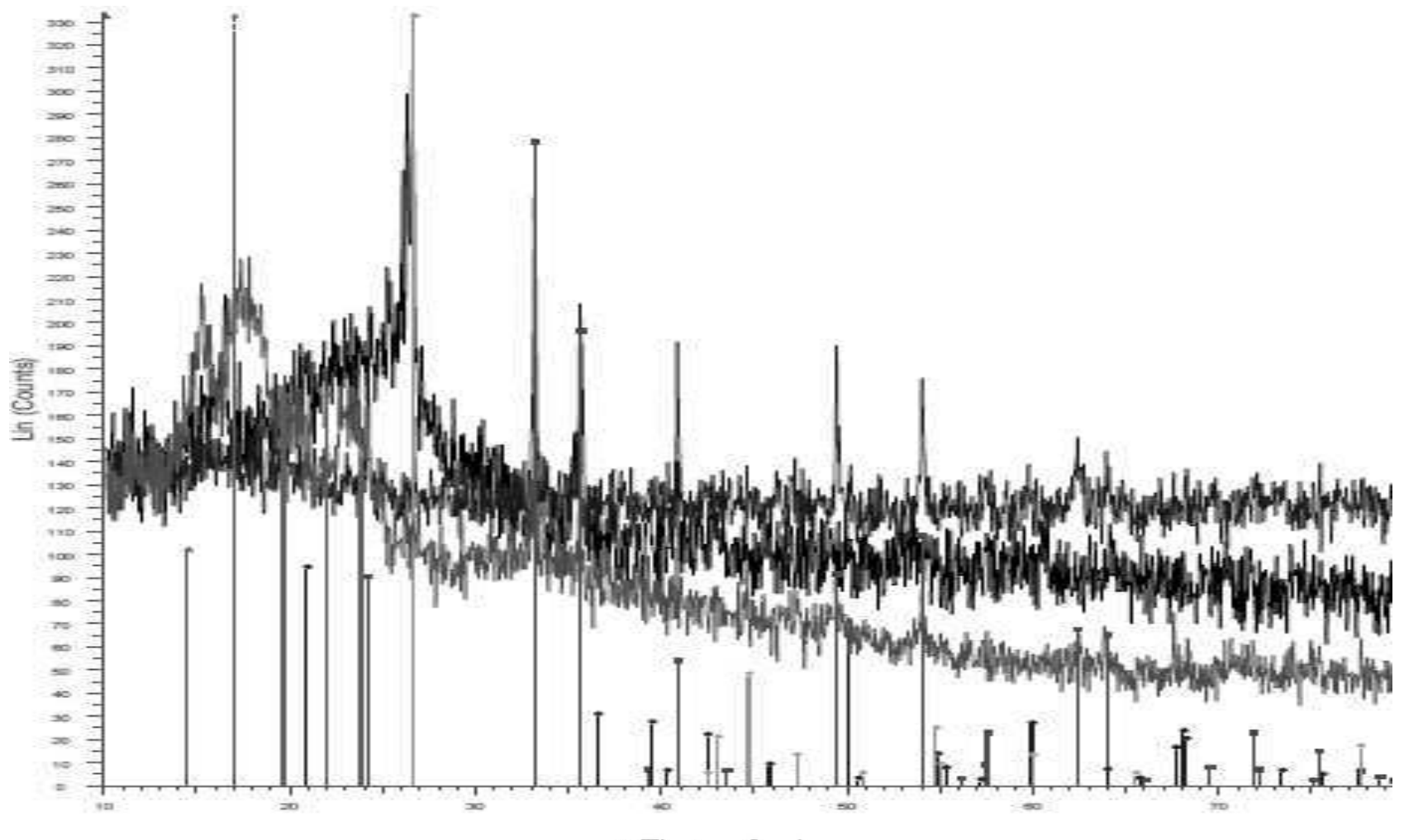

2-Theta - Scale

团 A - File: AA.raw - Type: 2 Th $/$ Th locked - Start: $10.000^{\circ}$ - End: $80.000^{\circ}$ - Step: Operations: Import

团 I - File: Il.raw - Type: 2 ThTh locked - Start: $10.000^{\circ}$ - End: $80.000^{\circ}$ - Step: 0 .

00-026-1080 (C) - Carbon - C - Y: $116.75 \%$ - d x by: 1. - WL: 1.5406 - Hexag $\triangle 00-055-1803$ (Q) - Starch (maize) - (C6H1005)n - Y: $100.37 \%-d x$ by: 1. - W Operations: Y Scale Mul 0.500 | Import

Wf F - File: FF.raw - Type: 2 Th/Th locked - Start: $10.000^{\circ}$ - End: $80.000^{\circ}$ - Step: Operations: Y Scale Mul 0.375 | Import

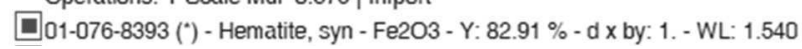

Fig. 8 Phase composition of used additives and new Surwaybest additive 
After proper analysis of the options, the Surveybest additive was produced and offered to the foundry production process, where its use was proven and the castings were made without any veining or toher casting defects.

\section{Discussion of the results}

The following diagram provides an algorithm for the elimination of veining, created based on the knowledge gained from the experimental work. Veining can be eliminated by:
- Control of input raw materials

- Grain size distribution of the sand

- Use of coating

- Changes in the dosage of the core mixture

- Adding a non-silica sands to the core mixture

- Decreasing the casting temperature

- Reducing the blowing pressure

- Addition of additives to the core mixture

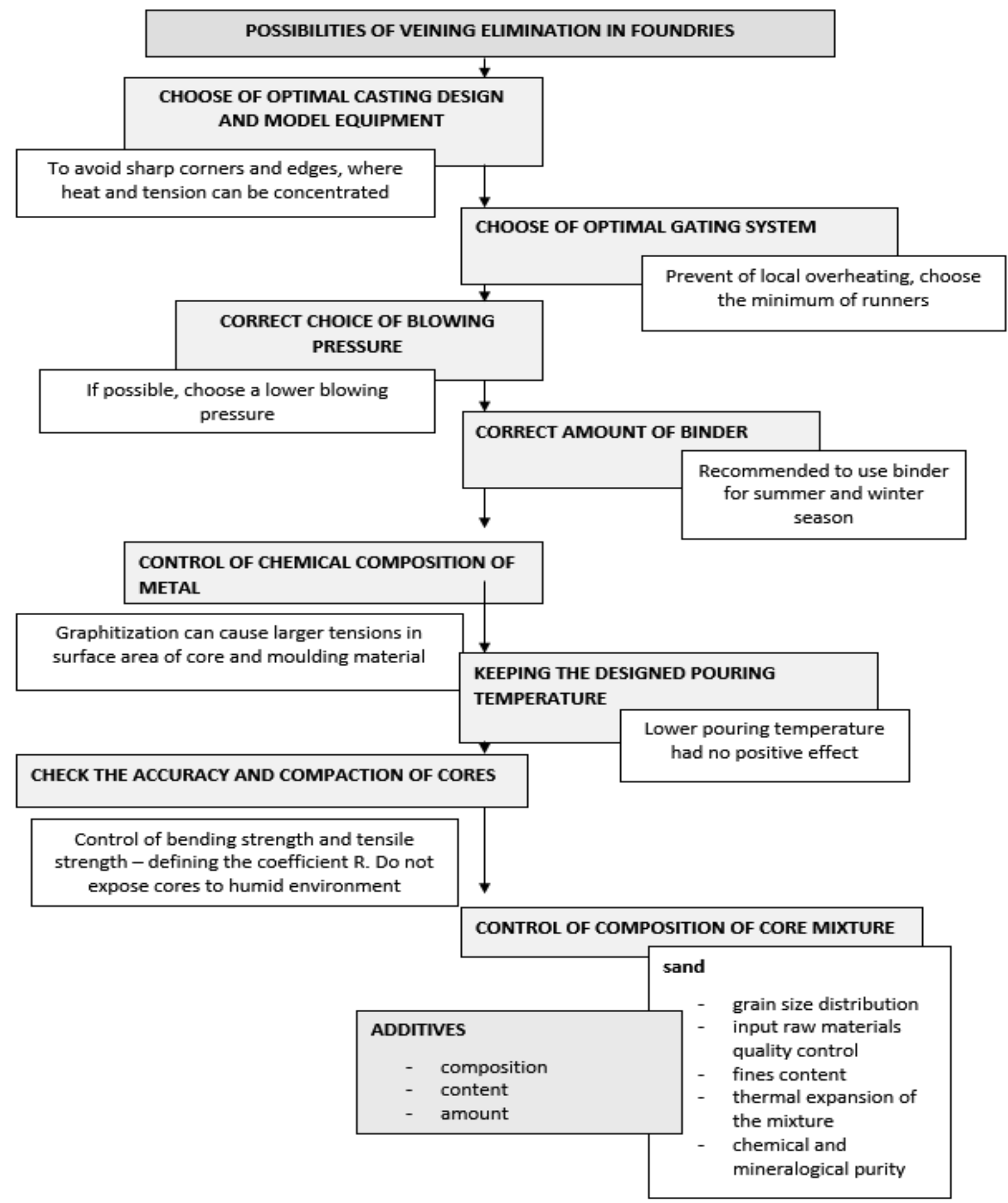

Fig. 9 Possibilities of veining elimination in foundries 


\section{Conclusion}

It should be noted that the foundry industry is a "beautifully vicious" circle not only of raw materials, so what is valid in one foundry, might not be in the others. The following operations have proven to be effective in eliminating veining on casting surfaces:

- Check the quality of input raw materials, their chemical and mineralogical purity.

- Use coatings on manufactured cores to prevent penetration of liquid metal.

- Use a silica sand with higher fines content.

- Reduce the blowing pressure of the machine to achieve lower compaction in order to create space for expansion between quartz grains.

- Use of non-silica sands in the core mixture.

Last but not least, we recommend the use of additives in the core mixture, which fulfill their purpose, but with the supply of additives in their present form - without the necessary information in the technical data sheet, it is assumed that they may cause complication when they enter the circle of the foundry in the long-term use. Therefore, it is recommended to use the newly designed Surwaybest additive based on a carbon reducing agent. $[11,12]$

\section{References}

[1] PRASS, I. (2015). Core blowing process. Casting College: Core Manufacturing. Presentation, 2015

[2] VASKOVÁ, I., HRUBOVČÁKOVÁ, M. (2015). Burrs from cores produced by cold-box- amine method and possibility of their elimination in Eurocast Košice s.r.o. company. Archives of foundry engineering. Vol. 15, special No. 1 (2015), p. 115120. ISSN 1897-3310.

[3] VASKOVÁ, I., HRUBOVČÁKOVÁ, M. (2015). Possibilities of burrs elimination from cores produced with cold-box-amine technology. News of science and education: Pedagogical sciences medicine construction and architecture technical sciences. No. 11 (35) (2015), p. 103-111. ISSN 2312-2773.
[4] Sand for casting mold, manufacturing method for sand casting-mold, and core for metal casting. European patent EP $2921243 \mathrm{~A} 1$. International publication number WO 2014/077203. 2014.

[5] SIBELCO MINERALS AND CHEMICALS LTD. Special sands for the foundry industry. Company materials. 2003.

[6] HRUBOVČÁKOVÁ, M., VASKOVÁ, I., BENKOVÁ, M., CONEV, M. (2016). Opening material as the possibility of elimination veining in foundries. Archives of Foundry Engineering. Vol. 16, No. 3 (2016), p. 157-161. ISSN 18973310 .

[7] SCHEEL, B. (2003). et al. Production avec zèro deéfaut: illuision ou realité? Hommes et Fonderie. No. 333, April 2003, p. 60-65.

[8] HRUBOVČÁKOVÁ, M., VASKOVÁ, I., CONEV, M. (2015). Vplyv zloženia jadrovej zmesi na výskyt výronkov na odliatkoch z jadier vyrobených technológiou cold-box-amín. In: Quo vadis zlievarenstvo 2015. Košice: TU, 2015 p. 4252. - ISSN 978-80-553-2226-1.

[9] ADAMOVITS, M., HORTON, K. (1998). Optimize your Cold Box Core Process (Optimajizujte svoji výrobu jader postupem Cold Box). Modern Casting. Vol. 88, No. 3 (1998), p. 43-47.

[10] HRUBOVČÁKOVÁ, M., VASKOVÁ, I., CONEV, M., BARTOŠOVÁ, M., FUTÁS̆, P. (2017). Influence the composition of the core mixture to the occurrence of veining on castings of cores produced by cold-box-amine technology. Manufacturing Technology. Vol. 17, No. 1 (2017), p. 39-44. ISSN 1213-2489.

[11] FOTI, R. (2000). A look back at the 20.th century: Part 4. Cold Box coremaking. Modern Casting. Vol. 90, No. 4 (2000), p. 56-57.

[12] HRUBOVČÁKOVÁ, M., VASKOVÁ, I. (2015). Possibilities of burrs elimination from cores produced with cold-box-amine technology. Acta Metallurgica Slovaca. Vol. 21, No. 1 (2015), p. 78-85. ISSN 1335-1532. 